\title{
Waste-activated sludge disruption by dry ice: bench scale study and evaluation of heat phase transformations
}

\author{
Alicja Machnicka $^{1} \cdot$ Klaudiusz Grübel $^{1}$ (D) $\cdot$ Stanisław Wacławek ${ }^{2} \cdot$ Krzysztof Sikora $^{3}$
}

Received: 8 April 2019 / Accepted: 1 July 2019 / Published online: 9 July 2019

(C) The Author(s) 2019

\begin{abstract}
The freezing process consists of dissipating heat from the product until the final temperature is lower than the temperature of crystallisation of that product. Freezing can be used for numerous applications, including for disruption of waste-activated sludge (WAS). The aim of this study was to calculate the estimated amount of heat conveyed between the solidified carbon dioxide and the WAS, in the following ratios: $0.25: 1 ; 0.5: 1 ; 0.75: 1$ and $1: 1$. In heat of phase transformations, dry ice sublimation, water solidification, the amount of heat transferred by other substances and heat transferred from the sludge (dry sludge) were taken into account during the process of WAS freezing. Heat changes on the surface of WAS were registered using a thermovision camera. The effectiveness of WAS disintegration was confirmed by several biochemical parameters such as soluble chemical oxygen demand (increase over 14 times), degree of disintegration (48\%), proteins (increase over 5 times), carbohydrates (increase almost 7 times), RNA (increase by $2.23 \mathrm{mg} \mathrm{L}^{-1}$ ), ammonia nitrogen (increase over 23 times), phosphates (increase almost 27 times) and turbidity (increased over 7 times). It was found that dry ice pretreatment of WAS can be an intriguing alternative for the conventional methods used.
\end{abstract}

Keywords Dry ice $\cdot$ Waste-activated sludge $\cdot$ Phase transformation processes $\cdot$ Organic and inorganic matter $\cdot$ Infrared radiation

\section{Introduction}

Technological development, population growth and improvement in the quality of life bring about an increase in the amount of sewage sludge. On the other hand, the tightening of regulations forces treatment plants to search for highly efficient methods of purifying sewage and recycling sewage

Responsible editor: Bingcai Pan

Electronic supplementary material The online version of this article (https://doi.org/10.1007/s11356-019-05889-2) contains supplementary material, which is available to authorized users.

Klaudiusz Grübel

kgrubel@ath.bielsko.pl

1 Faculty of Materials, Civil and Environmental Engineering, University of Bielsko-Biala, Willowa 2 STR, 43-300 Bielsko-Biala, Poland

2 Centre for Nanomaterials, Advanced Technologies and Innovation, Technical University of Liberec, Liberec, Czech Republic

3 Faculty of Mechanical Engineering and Computer Science, University of Bielsko-Biala, Willowa 2 STR, 43-300 Bielsko-Biala, Poland sludge. With the guidelines of the European Union, it is aimed to maximally reuse the sewage sludges, both on the stage of recovery of products and minimisation of sludges, as well as final management. Agricultural management of sludges is subject to strict regulations and storage requires development of a strategy, which aims to reduce the amount of biodegradable waste (Babatunde and Zhao 2007).

Over the past few years, the advantages of sewage sludge disintegration processes have been discovered, such as sewage sludge conditioning and increasing the efficiency of stabilisation processes. Disintegrative treatment methods of sewage sludges belong currently to the most dynamically developing technologies. They concern mainly the possibility of reducing the amount of sludge discharged from sewage treatment plants (Liu et al. 2016; Machnicka and Grübel 2016) and improvement of susceptibility of the sludge into a biochemical decomposition (Kardos et al. 2011; Wacławek et al. 2016; Liu et al. 2019). Disintegration is a process of destroying the structure of the sludge, which involves fragmenting of flocs, destruction of cells of microorganisms and releasing organic substances, inorganic substances and extracellular polymers into the supernatant of the sludge (Yu et al. 2008; Grübel et al. 2014). Sewage sludge pretreatment uses a variety of disintegration methods, such as high pressure (Gogate et al. 
2001; Mirota et al. 2011); mechanical (Müller 2000; Wett et al. 2010); microwave (Kuglarz et al. 2014; Yi et al. 2014); ultrasound energy (Şahinkaya and Sevimli 2013; Zhou et al. 2015; Aylin Alagöz et al. 2018); chemical methodsozonisation (Ak et al. 2013; Silvestre et al. 2015; Carbajo et al. 2016; Xu et al. 2018), alkalisation (Yan et al. 2013; Suschka et al. 2015; Silvestri et al. 2018a), acidification (Wang et al. 2014; Li et al. 2016; Parthiba Karthikeyan et al. 2018) and oxidation technique (Zhang et al. 2015; Lu et al. 2016; Wacławek et al. 2017; Kim et al. 2018); biological methods - enzymes (Jang et al. 2014; Kavitha et al. 2014; Lü et al. 2016; Gebreeyessus and Jenicek 2016; Ali et al. 2018) and thermal methods (heat pretreatment, freezing/ thawing) (Montusiewicz et al. 2010; Carrère et al. 2010; Nowicka and Machnicka 2015; Pilli et al. 2015; Liu et al. 2018); and hybrid methods (a combination of at least two disintegration techniques) (Zhang et al. 2012; Uma Rani et al. 2014; Grübel and Suschka 2015; Suschka and Grübel 2016; Grübel et al. 2018).

Depending on the disintegration method used, there can be indicated the advantages and disadvantages of each of them. All methods cause effective destruction/disintegration which can be expressed by the so-called degree of disintegration (calculated based on the release of organic matter - soluble chemical oxygen demand (SCOD)), which increases, for example, for ultrasonic disintegration to $57.9 \%$ (Kidak et al. 2009), and for hydrodynamic to $28-35 \%$ (Grübel and Suschka 2015). Among the disadvantages of listed methods, the following could be mentioned: the demand for energy consumption and chemical reagents request, time and conditions of the processes of effective disintegration. The mentioned methods were often discussed in the review articles (Pérez-Elvira et al. 2006; Carrère et al. 2010; Tyagi and Lo 2011).

Another method for sludge pretreatment in the process of freezing presented in this article is an application of dry ice. Dry ice transforms the flocs structure into larger agglomerates and reduces bound water (Jean et al. 2001).

Dry ice or solid carbon dioxide is a completely natural product. It is produced in the form of granules, beads or prills by the compression gaseous carbon dioxide to liquid form, removing the heat generated by compression, and then rapid expansion. By expansion and rapid evaporation of carbon dioxide gas-remaining fluid, which was cooled to the melting point and frozen in the $\mathrm{CO}_{2}$ 'snow', beads or prills take form. The dry ice sublimes were at $194.65 \mathrm{~K}$ at a pressure of $1013.25 \mathrm{hPa}$ (Jean et al. 2001; Jeyasekaran et al. 2006). Heat of sublimation is $573 \mathrm{~kJ}$, which means that it is approximately 3.3 times more effective as a coolant than water ice (with the same volume). It is anhydrous, non-flammable and non-toxic and has no smell or taste (Ismalaj and Sackett 2015).

Destructive effects of low temperature on the wasteactivated sludge (WAS) bind with a group of factors such as rate of freezing and thawing, chemical composition of the environment of microorganisms, species, time of freezing and temperature. However, mechanical destruction of the cells of microorganisms with the use of ice crystals, which rapture them from the inside or damage them from the outside, is put on the first place. Moreover, the process by dry ice freezing of WAS can cause the following: destruction of sludge flocs structure, increase of the volume of freezing water in the cytoplasm, mechanical damage to the wall and/or cytoplasmic membranes of microorganisms, osmotic shock, decrease of the stability of secondary structures of RNA and DNA, and reduction of the efficiency of transcription, translation, replication of DNA in cells, and 'cold' death of microorganisms (Seviour and Nielsen 2010).

In many technological processes, rapid heat energy introduction and dissipation is essential. Emitting or absorbing large quantities of heat during phase transformations has been used in cooling and air-conditioning devices for many years (Wiktor et al. 2015). Various media that are used are characterised by a large heat capacity, which is the ratio of specific heat to volume. One of the best substances for this purpose is water, where its specific heat is equal $4.18 \mathrm{~kJ} \mathrm{~kg}^{-1}$ $\mathrm{K}^{-1}$ and its volume is approx. $1000 \mathrm{~kg} \mathrm{~m}^{-3}$. However, even in this case, the amount of heat exchanged with a different factor is considerably lower than in the case of substance phase transformation (Zalba et al. 2003; Sharma et al. 2009). The method of cooling products in tavern basements with ice amassed during winter had been used for many centuries. This is why for the rapid cooling of WAS containing 92 94\% water (Wójcik et al. 2017), it seems advantageous to use a substance that undergoes phase transformation at low temperatures. Dry ice is such a substance, as its sublimation temperature is approx. $194.65 \mathrm{~K}$ and sublimation heat is equal $573 \mathrm{~kJ} \mathrm{~kg}^{-1}$.

This paper focuses on the possibility of application of WAS disintegration by dry ice method and its efficiency. Herein, we have observed changes in several parameters, i.e. SCOD, proteins, $\mathrm{RNA}, \mathrm{PO}_{4}{ }^{3-}, \mathrm{N}-\mathrm{NH}_{4}{ }^{+}$and carbohydrate concentration in the WAS liquid, and CST parameter, before and after the disintegration. Moreover, FTIR was used for detailed evaluation of change in organic content after this pretreatment.

\section{Materials and methods}

\section{Waste-activated sludge samples}

WAS samples were collected in 10-L containers and transported from wastewater treatment plant (WWTP), located in the Silesian voivode ship in Poland, to the laboratory of University of Bielsko-Biala. WWTP operates according to the Enhanced Biological Nutrient Removal (EBNR) processes and WAS samples were taken from outflow of secondary 
settling tanks. The main characteristics of WAS are as follows: $\mathrm{pH} 7.1 \pm 0.2$, total solids (TS) $11.81 \pm 0.51 \mathrm{~g} \mathrm{~L}^{-1}$, volatile solids (VS) $8.16 \pm 0.62 \mathrm{~g} \mathrm{~L}^{-1}$, soluble chemical oxygen demand (COD) $61 \pm 8 \mathrm{mg} \mathrm{L}^{-1}$, total COD $9.82 \pm 0.74 \mathrm{mg} \mathrm{L}^{-1}$, soluble ammonium nitrogen $\left(\mathrm{N}^{-\mathrm{NH}_{4}}{ }^{+}\right) 2.4 \pm 0.2 \mathrm{mg} \mathrm{L}^{-1}$ and soluble phosphate $\left(\mathrm{P}^{-} \mathrm{PO}_{4}{ }^{3-}\right) 13.7 \pm 0.5 \mathrm{mg} \mathrm{L}^{-1}$.

\section{Dry ice}

Dry ice used for disintegration was in the form of prills/pellets and was obtained from the company Cryopoland sp. $\mathrm{z}$ o.o. Dry ice to the laboratory was transported in thermostatic containers that prevented the sublimation of dry ice.

Dry ice was produced in a pelletiser which is manufactured by taking pressurised liquid $\mathrm{CO}_{2}$ (horizontal storage vessel installed close to the production unit) and allowing it to expand into the natural atmosphere. This causes the liquid $\mathrm{CO}_{2}$ to expand into both a gas vapour and solid snow. Liquid $\mathrm{CO}_{2}$ is injected into chambers inside the production machines, creating pressure, and liquid $\mathrm{CO}_{2}$ expands; $\sim 1 \mathrm{~kg}$ of liquid $\mathrm{CO}_{2}$ is flashed to make $0.45 \mathrm{~kg}$ of dry ice. The snow is then either compressed or extruded to form pellets. Generally, it is desirable to have dry ice pellets that are well compacted to minimise the entrapment of gaseous $\mathrm{CO}_{2}$ and/or air which may affect product quality. These dry ice pellets are generally in the order of 0.2 to $0.3 \mathrm{~cm}$ in diameter and 0.25 to $1 \mathrm{~cm}$ in length.

\section{Disintegration of WAS by freezing}

Disintegration by freezing of a 1-L WAS sample was done by dry ice. The used volume ratios of the WAS to dry ice and time of disintegration (sublimation) are presented in Table 1.

\section{Methodology of phase transformation processes}

In heat of phase transformations, dry ice sublimation, water solidification and also the amount of heat transferred by other substances and heat transferred from the sludge (dry sludge-without water) should be taken into account when preparing the energy balance for the process of freezing sludge. The heat absorbed from the environment

Table 1 The used volume ratios of the WAS to dry ice and time of disintegration (sublimation)

Volume ratio of WAS

to dry ice

\begin{tabular}{ll}
\hline $1: 0.25$ & 1.5 \\
$1: 0.50$ & 2.0 \\
$1: 0.75$ & 3.0 \\
$1: 1$ & 4.5 \\
\hline
\end{tabular}

during substance mixing is relatively low (according to calculations, approx. $5 \mathrm{~kJ}$ ) and can be omitted in the overall energy balance. Exact energy balancing is extremely difficult, due to the mixing of sludge and dry ice being impeded by the rapid water solidification. Zones differing in temperature are formed, depending on the chemical composition of the specific area. Exact modelling of phase transformation processes can be found in scientific writing (Amano and Sunden 2010; Gugulothu et al. 2019). However, using the energy balance, it is possible to establish, in good approximation, the amount of dry ice needed to freeze sludge. When dry ice sublimates, it takes energy away from the sludge, causing water to freeze and bringing about the subsequent cooling of the sludge. By simplifying this process, it can be assumed that in the end stage, the temperature would be uniform in the entire volume. This assumption allows to formulate the energy balance equation, where one side contains factors attributed to dry ice (the amount of energy absorbed by dry ice when sublimating and later heating to end temperature) and the other side contains factors attributed to the sludge. The amount of heat absorbed by dry ice can be calculated using the following equation:

$Q_{\mathrm{CO}_{2}}=m_{\mathrm{CO}_{2}} \cdot c_{s}+m_{\mathrm{CO}_{2}} \cdot\left(t_{k}-t_{s}\right) \cdot c_{w_{\mathrm{CO}_{2}}}$

where $Q_{\mathrm{CO}_{2}}$ is the heat absorbed by $\mathrm{CO}_{2} ; m_{\mathrm{CO}_{2}}$ is the $\mathrm{CO}_{2}$ weight; $c_{s}$ is the sublimation heat; $t_{k}$ is the end temperature of mixture; $t_{s}$ is the sublimation temperature; $c_{w_{\mathrm{CO}_{2}}}$ is the specific heat of $\mathrm{CO}_{2}$ (gas).

The amount of heat conveyed by WAS can be calculated using the following equation:

$$
Q_{o}=Q_{s}+Q_{w}(2)
$$

where $Q_{o}$ is the heat conveyed by sludge; $Q_{s}$ is the heat conveyed by solid sludge components; $Q_{w}$ is the heat conveyed by water found in sludge.

The heat conveyed by solid sludge components which do not undergo phase transformations can be calculated using the following equation:

$Q_{s}=c_{w s} \cdot m_{s} \cdot\left(t_{k}-t_{p}\right)$

where $c_{w s}$ is the specific heat of solid sludge components; $m_{s}$ is the weight of solid sludge components; $t_{p}$ is the start sludge temperature.

The amount of heat emitted by water can be calculated based on the weight ratio of the mixed dry ice and WAS. The reason for this is that during the first stage the energy that is absorbed by the dry ice causes the cooling of the sludge. After reaching $273.15 \mathrm{~K}$, the temperature stops decreasing, because the heat absorbed by the dry ice causes the phase transformation of water into ice. Only after all the water 
freezes does the temperature continue to decrease. Based on this, three ranges may be determined where the heat emitted by the water was calculated:

for $t_{k}>273.15 \mathrm{~K}$

$Q_{w}=c_{w} \cdot m_{w} \cdot\left(t_{p}-t_{k}\right)$

where $Q_{w}$ is the heat emitted by water; $m_{w}$ is the water weight; $c_{w}$ is the specific heat of water;

for $t_{k}=273.15 \mathrm{~K}$

$Q_{w}=c_{w} \cdot m_{w} \cdot\left(t_{p}-t_{k}\right)+Q_{k}$

In this equation, it is only possible to calculate the amount of heat emitted during the solidification of water $Q_{k}$ based on the system's energy balance when the components' volume fraction is known.

For $t_{k}<273.15 \mathrm{~K}$

$Q_{w}=c_{w} \cdot m_{w} \cdot\left(t_{p}\right)+m_{w} \cdot c_{k}+m_{w} \cdot c_{w l} \cdot\left(-t_{k}\right)$

where $c_{w l}$ is the specific heat of ice; $c_{k}$ is the heat of water solidification.

In this experiment, it is essential for the entire sludge to freeze; therefore, the minimal amount of dry ice needed for this purpose can be calculated as:

$m_{\mathrm{CO}_{2}}=\frac{c_{w} \cdot m_{w} \cdot\left(t_{p}\right)+m_{w} \cdot c_{k}+c_{w s} \cdot m_{s} \cdot\left(t_{p}\right)}{c_{s}+c_{w_{C O}} \cdot\left(-t_{s}\right)}$

From the equation above, it is also possible to determine the average end temperature, when the mixture composition is known. However, as it was previously mentioned, the above calculations are an approximation due to the phenomenon's complexity; the errors are minimal. This will be shown in further calculations.

The surface of the reactors was registered using a FLIR E50 thermovision camera.

\section{Physicochemical analysis}

In the WAS samples, before and after the process of disintegration by dry ice, the following were determined indicative of the release of organic and inorganic matter: soluble chemical oxygen demand (SCOD) value, concentration of proteins, carbohydrates, RNA acid, ammonia nitrogen, phosphates and turbidity value in the liquid phase.

SCOD, ammonia nitrogen, phosphates and turbidity value were determined for samples before and after disintegration by dry ice according to the Standard Methods for Examination of Water and Wastewater (22nd ed.) (Rice and Bridgewater 2012). The protein concentration was determined by the Lowry methods (Gerhardt et al. 1994). The carbohydrate concentration was determined by the Anthron methods (Kreith and Tchobanoglous 2002). The concentration of cellular ribonucleic acid (RNA) in the WAS samples before and after disintegration was determined by the method presented in the work of Liwarska-Bizukojc and Ledakowicz (2001). According to this methodology, a sample of WAS $(5 \mathrm{~mL})$ was diluted and washed three times with $3 \mathrm{~mL}$ cold $0.7 \mathrm{M}$ $\mathrm{HClO}_{4}$ to destroy the cell walls of bacteria. Then, WAS was mixed with $3 \mathrm{~mL} 0.3 \mathrm{M} \mathrm{KOH}$ solution and held for $60 \mathrm{~min}$ at $37^{\circ} \mathrm{C}$ (every $5 \mathrm{~min}$, samples were mixed to hydrolyse RNA). The post-hydrolysis supernatant was collected and the precipitate was washed twice with $3 \mathrm{~mL}$ cold $0.5 \mathrm{M} \mathrm{HClO}_{4}$. Finally, all extracts were made up to $15 \mathrm{~mL}$ with $0.5 \mathrm{M} \mathrm{HClO}_{4}$ and centrifuged to remove any remaining solid particles. The obtained supernatant was subjected to the absorbance measurement (absorbance of released purines and pyrimidines) by spectrophotometer HACH DR5000 (wavelength $260 \mathrm{~nm}$ ). The concentration of RNA was calculated according to the formula:

$C_{\mathrm{RNA}}=\frac{A_{260} \cdot M_{w}}{\varepsilon l} R$

where $M_{W}=340 \mathrm{~g} \mathrm{~mol}^{-1}$ is the average nucleotide molar weight; $R$ is dilution; $\varepsilon=10,800 \mathrm{~mol} \mathrm{~cm}{ }^{-1}$ is the molar absorption coefficient; $l$ is the length of measuring cell $(\mathrm{cm})$.

The results were taken from analyses performed at least 5 times; arithmetic average was calculated. The standard deviation was determined according to the estimator of the highest credibility in Statistica 6.0.

\section{The degree of disintegration}

In order to obtain a quantitative measure of the effects of disintegration, the coefficient called the degree of disintegration (DD) was used for calculation according to methodology given by Müller (Müller 2000) and used earlier by our research group (Grübel and Machnicka 2013).

\section{Infrared waves}

To confirm the release of various chemical compounds from the cells of microorganisms during the destruction of WAS by dry ice, the infrared wave analysis (IR) was applied.

A spectrometer Nicolet Magna IR 860 (Thermo Electron Corporation, USA) was used. The analysis of IR spectroscopy was carried out on suspension from evaporated liquid phase WAS samples before and after disintegration. The samples were mixed with $\mathrm{KBr}(1 \mathrm{mg}: 200 \mathrm{mg})$ and compressed in $500 \mathrm{MPa}$ into pellets at $13-\mathrm{mm}$ disc size; the background was a reference of pure $\mathrm{KBr}$. The spectra were registered at a $4-\mathrm{cm}^{-1}$ resolution in the range from 4000 to $400 \mathrm{~cm}^{-1}$ with 128 scans per spectrum. Data collection and post-processing were performed using OMNIC software (v. 8.0, Thermo 
Electron Corp.) which allows to compare obtained spectra in the scope of absorbance proportionally to the amount of the drawn sample, which allowed for quantitative interpretation of the results.

\section{Capillary suction time}

The measurement of the capillary suction time (CST) was carried out according to Baskerville's and Galle's methodology based on the measurements of transition of frontal boundary layer of the filtrate as a result of the effect of suction forces in the used paper (Whatman 17).

\section{Results and discussion}

Our investigations on the disintegration of WAS using dry ice concerned two aspects. The first was the dry ice and WAS energy balance analysis, taking into account phase transformations. The aim of this was to determine the mixture's end temperature (with various WAS-dry ice ratio).

\section{The evaluation of heat phase transformations}

The physical properties and thermodynamic parameters used in the calculations are presented in Table 2.

Theoretical amount of dry ice needed to freeze the sludge was calculated according to Eq. 7 and was $0.605 \mathrm{~kg} \mathrm{CO}_{2}$.

For the mixture 1:0.25 (ratio of WAS to dry ice), the calculation showed that the amount of absorbed energy during the sublimation of dry ice and its subsequent heating to $273.15 \mathrm{~K}$ was approx. $\mathrm{Q}=207 \mathrm{~kJ}$, whereas to freeze the sludge, at least $387 \mathrm{~kJ}$ of heat emission was required. Therefore, the temperature of $273.15 \mathrm{~K}$ for this mixture composition was achieved, because part of the water froze and some remained in liquid state.

Calculations for the 1:0.5 ratio mixture showed that the solid carbon dioxide absorbs approx. $410 \mathrm{~kJ}$ of energy; therefore, the temperature of the mixture should be around 263.15 K. The temperature of $267.15 \mathrm{~K}$ (Fig. 1b) was determined after taking into account the average amount of heat absorbed during wall condensation caused by air humidity (when air

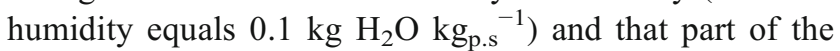

$\mathrm{CO}_{2}$ is released and leaves the system, only partially absorbing heat form the sludge $(80 \%$ of theoretical amount of absorbed heat). The surface of the mixtures ratio (WAS-dry ice) was registered using a FLIR E50 thermovision camera and is shown in Fig. 1.

Calculations for the 1:0.75 ratio mixture showed that the $\mathrm{CO}_{2}$ absorbs approx. $558 \mathrm{~kJ}$ of energy. The mixture should therefore reach the temperature equal to the temperature of dry ice sublimation. The amount of absorbed heat during the sublimation transformation of such an amount of dry ice causes the freezing of sludge and then its further cooling to approximately $194.65 \mathrm{~K}$. Theoretical calculations assume temperature levelling in the entire mixture volume. This is theoretically possible only after accurate isolation of the mixture and complete sublimation of the dry ice. In practice, it is not possible to reach this state, due to the forming of an ice coat around the fragments of dry ice, which hinders the sublimation process. Despite this, in Fig. 1c, it is possible to observe temperature points that go beyond the range of the thermovision camera.

Even considerably higher temperature points were also found. These are found on the edges of the container and on larger ice fragments. It can be assumed that if the system was left in isolation longer (not frozen at once), the temperature would be much more uniform in the entire mixture volume.

Calculations for the 1:1 ratio mixture showed that the $\mathrm{CO}_{2}$ absorbs approximately $745 \mathrm{~kJ}$ of energy. As was in the previous case, the amount of absorbed energy is enough to reach the sublimation temperature, which is ca. 194.65 K. Similarly as in the previous case, it is impossible to reach this temperature in the entire volume in a short space on time due to the heterogeneity within the mixture's volume (solid and liquid state of WAS). Large areas going beyond the camera's range can be observed on the thermovision image (Fig. 1d). The application of a mechanical stirrer capable of crumbling the formed ice fragments would cause quicker uniform sludge cooling.

We used variable volumetric values of dry ice to WAS. This methodology contributed to the different time of disintegration of the WAS. A small proportion of dry ice (1:0.25) did not cause complete freezing of the entire sample volume and the thawing was fastest (this was also confirmed by observation using a thermal imaging camera and calculations of heat
Table 2 The physical properties and thermodynamic parameters used in the calculations

\begin{tabular}{lllll}
\hline Substance & $\begin{array}{l}\text { Specific heat }(\mathrm{J} \\
\left.\mathrm{kg}^{-1} \mathrm{~K}\right)\end{array}$ & $\begin{array}{l}\text { Solidification heat } \\
\left(\mathrm{J} \mathrm{kg}^{-1}\right)\end{array}$ & $\begin{array}{l}\text { Sublimation heat } \\
\left(\mathrm{J} \mathrm{kg}^{-1}\right)\end{array}$ & $\begin{array}{l}\text { Average density } \\
\left(\mathrm{kg} \mathrm{m}^{-3}\right)\end{array}$ \\
\hline Water & 4181 & 334,000 & - & 1000 \\
$\mathrm{Ice}$ & 2095 & - & - & 917 \\
$\mathrm{CO}_{2}$ & 850 (gas) & - & 573,000 (dry ice) & 1300 (dry ice) \\
$\begin{array}{l}\text { Solid sludge components } \\
\text { (average) }\end{array}$ & 1950 & - & - & 1019 \\
\hline
\end{tabular}


Fig. 1 Surface temperature distribution of used mixtures. a 1:0.25. b 1:0.5. c 1:0.75. d 1:1
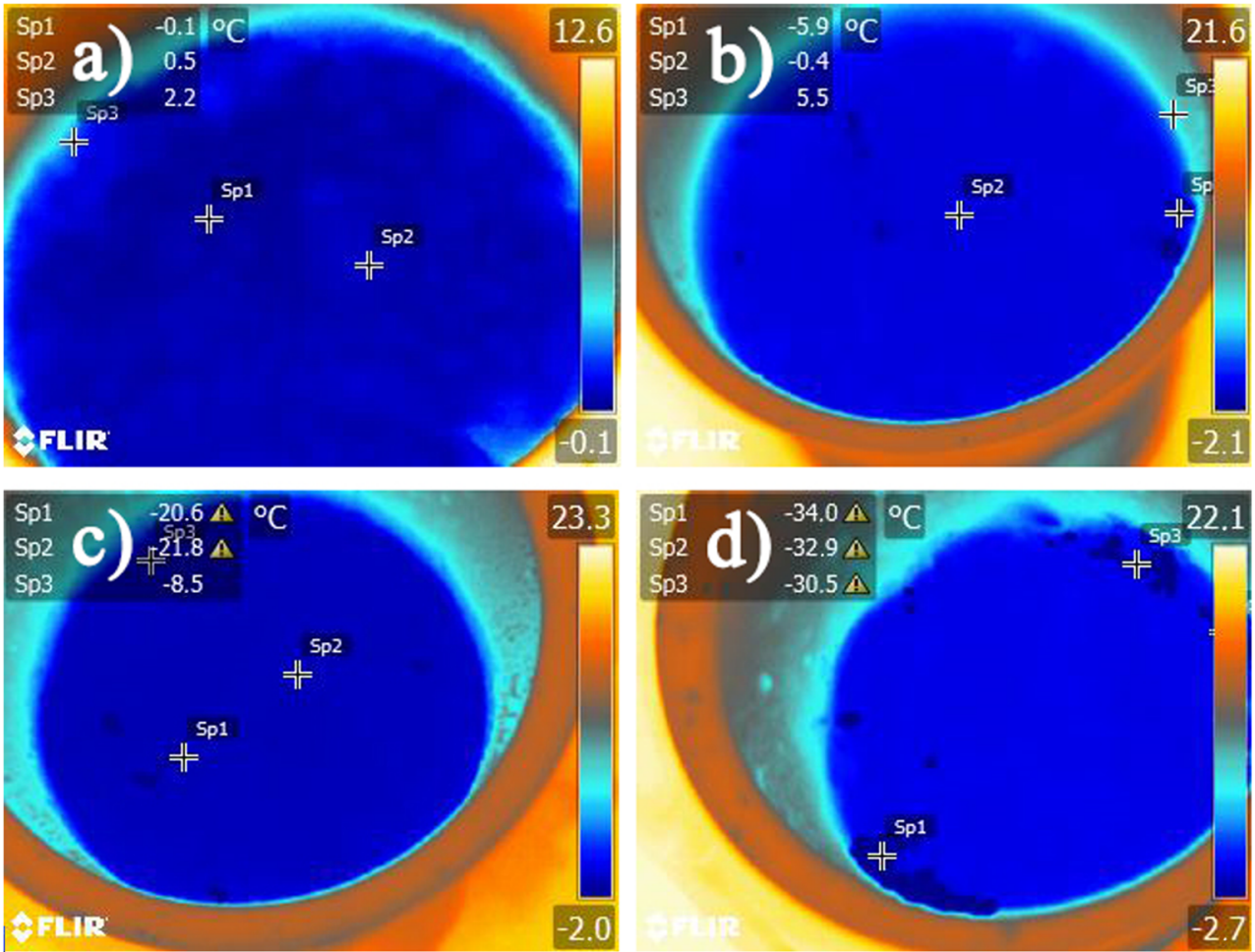

phase transformations). A dose of 1:0.75 and higher resulted in complete freezing of the samples and effective disintegration lasting 3-4.5 h.

\section{Changes in the chemical composition of supernatant}

During the next stage, we tried to evaluate the effect of the freezing phenomenon on the release of chemical compounds.

Disintegration of WAS by dry ice caused the release of organic matter (expressed as SCOD) to a supernatant of the sludge. Changes in SCOD were associated with the disruption of the WAS flocs and cells of microorganisms, which led to the release of organic compounds to the sludge liquid.

During the WAS disintegration by dry ice, the intensification of increase of SCOD was indicated, depending on the applied volume ratio of sludge to dry ice. Disintegration by dry ice for the volume ratio of the sludge to dry ice 1:0.25 contributed to the increase of SCOD from the initial value of $63 \mathrm{mg} \mathrm{O}_{2} \mathrm{~L}^{-1}$ (raw sludge) to $205 \mathrm{mg} \mathrm{O}_{2} \mathrm{~L}^{-1}$ (Fig. 2) and by increasing the dose of dry ice in relation to the sludge in a ratio of $1: 1$, SCOD achieved the value of $889 \mathrm{mg} \mathrm{O}_{2} \mathrm{~L}^{-1}$ (Fig. 2).

Chen et al. (2014) studied the effectiveness of freezing of sludges in order to increase degradation of organic substances to the benefit of growth in biogas production and the use of microbiological substrate in the fuel cell (MFC) to produce electric energy. The obtained results demonstrated that a long time of sludge freezing (more than $48 \mathrm{~h}$ ) resulted in release of substrate, which is susceptible to biochemical degradation process and provided the possibility of its processing into electric energy. The obtained about $40.9 \%$ higher removal efficiency of total SCOD and increase of maximum power output about $1.3 \mathrm{~W} \mathrm{~m}^{-3}$ in MFC.

The intracellular substances were released to the liquid phase as a result of crystallisation of flocs and microorganisms cells. Release of organic matter in the process of freezing was examined by $\mathrm{Hu}$ et al. (2004). They obtained more than $15 \%$ increase of the SCOD value.

Wang et al. (1999) compared the effects of thermal sonolysis with the effects of freezing in $-10{ }^{\circ} \mathrm{C}$ temperature and sonification. They found that the increase of the dissolved SCOD was higher for $40 \mathrm{~min}$ of sonification and freezing to -

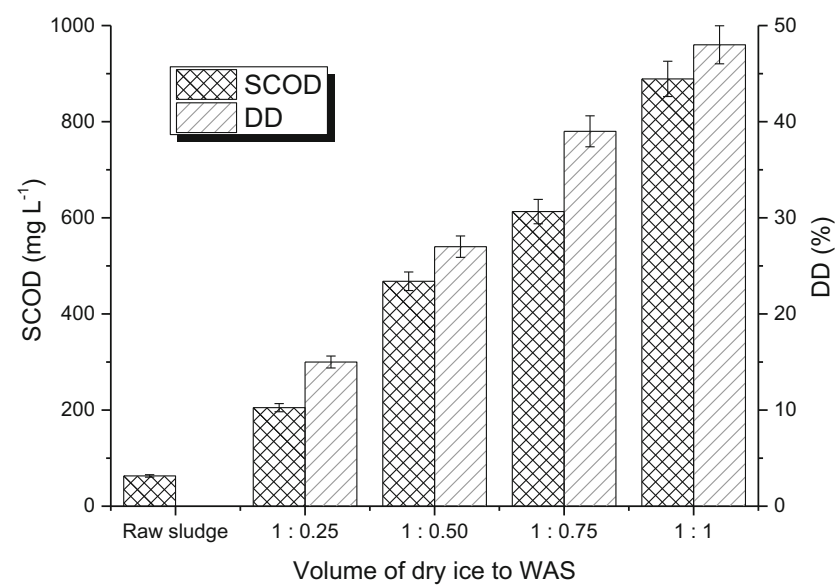

Fig. 2 Changes soluble chemical oxygen demand (SCOD) value and degree of disintegration (DD) before and after the disintegration of sludge by dry ice 
$10{ }^{\circ} \mathrm{C}$ temperature, while only sonification appeared to be ineffective. Therefore, one of the assumptions could be that freezing of sludge has a positive impact on the release of organic matter to a solution (however, it should be mentioned that the authors in article focused mainly on the combined pretreatment).

As expected, with the increase of the dose of the solid carbon dioxide $\mathrm{CO}_{2}$ in relation to the WAS, the disintegration degree of samples (DD) increased.

As a result of destructive effects of dry ice to the WAS structure for the volume ratio of WAS to dry ice 1:0.25, the DD increased to $15 \%$ (Fig. 2). A further increase of the volume of dry ice doses in relation to the WAS (the volume ratio of WAS to dry ice $1: 0.5 ; 1: 0.75 ; 1: 1)$ resulted in a further increase of the DD to $48 \%$ (Fig. 2).

A significant release of proteins was analogous to the increase in the value of SCOD. The increase in proteins concentration was related to the destructive effect of low temperatures on the cells of microorganisms and introducing enzymes and structural proteins to the solution (Örmeci and Aarne Vesilind 2001). The proteins concentration in the liquid phase of WAS increased from $56 \mathrm{mg} \mathrm{L}^{-1}$ (raw sludge) to $99 \mathrm{mg} \mathrm{L}^{-1}$ for the volume ratio of WAS to dry ice 1:0.25 (Fig. 2). A further increase of WAS to dry ice ratios caused progressive increase of proteins concentration in the solution to $291 \mathrm{mg}$ $\mathrm{L}^{-1}$ (Fig. 2).

Thus, disruption of WAS flocs and cells of microorganisms by disintegration by dry ice resulted in release of organic matter to the liquid sludge phase, expressed in the increase of the SCOD value, concentration of proteins and carbohydrates (Figs. 2 and 3).

The effectiveness of the process of freezing of WAS has been also expressed by change in the concentration of carbohydrates in the supernatant of the WAS. Disintegration of the
WAS by dry ice led to an increase of carbohydrate concentration in the liquid phase, from the initial value of $12 \mathrm{mg} \mathrm{L}^{-1}$ for raw WAS to the value of $83 \mathrm{mg} \mathrm{L}^{-1}$ for the volume ratio of WAS to dry ice of 1:1 (Fig. 3).

The impact of freezing on the release of organic and inorganic substances (for example, proteins, carbohydrates, phosphates) from the microorganisms cells was also shown by other researchers (Zaia et al. 2000; Örmeci and Aarne Vesilind 2001; Montusiewicz et al. 2010; Gao 2011; $\mathrm{Hu}$ et al. 2011).

Determining the origin of chemical compounds components of biomass in a liquid sewage sludge phase is often very difficult. Therefore, another compound, which confirms the destruction of cells of microorganisms is RNA (ribonucleic acid) in the sludge liquid. In the last decade, a number of researchers used Schneider's method with the use of hot perchlorid acid to determine the RNA or DNA concentration in a medium. Another method used in the studies is a technique which uses cold $\mathrm{HClO}_{4}$ and spectrophotometer (Liwarska-Bizukojc and Ledakowicz 2001).

Based on the conducted analysis on the effective action of dry ice on the microorganisms of the WAS, it has also been found that the increase of the dose of dry ice in relation to the sludge was followed by an increase of the concentration of RNA acid in the liquid of sludge samples. For the control sample (raw sludge), the concentration of RNA amounted to $10.07 \mathrm{mg} \mathrm{L}^{-1}$, while for the volume ratio of sludge to dry ice $1: 1$, the concentration of RNA increased by $2.23 \mathrm{mg} \mathrm{L}^{-1}$ (Fig. 3).

As a result of destruction of cells structure of microorganisms by dry ice, the release of enzymes contained in the protoplast of microorganisms took place, whose effect of hydrolytic action was decomposition of nitrogen and phosphorous organic compounds and thus, there was also an increase of
Fig. 3 Changes of proteins, carbohydrate and RNA concentration before and after disintegration of WAS by dry ice

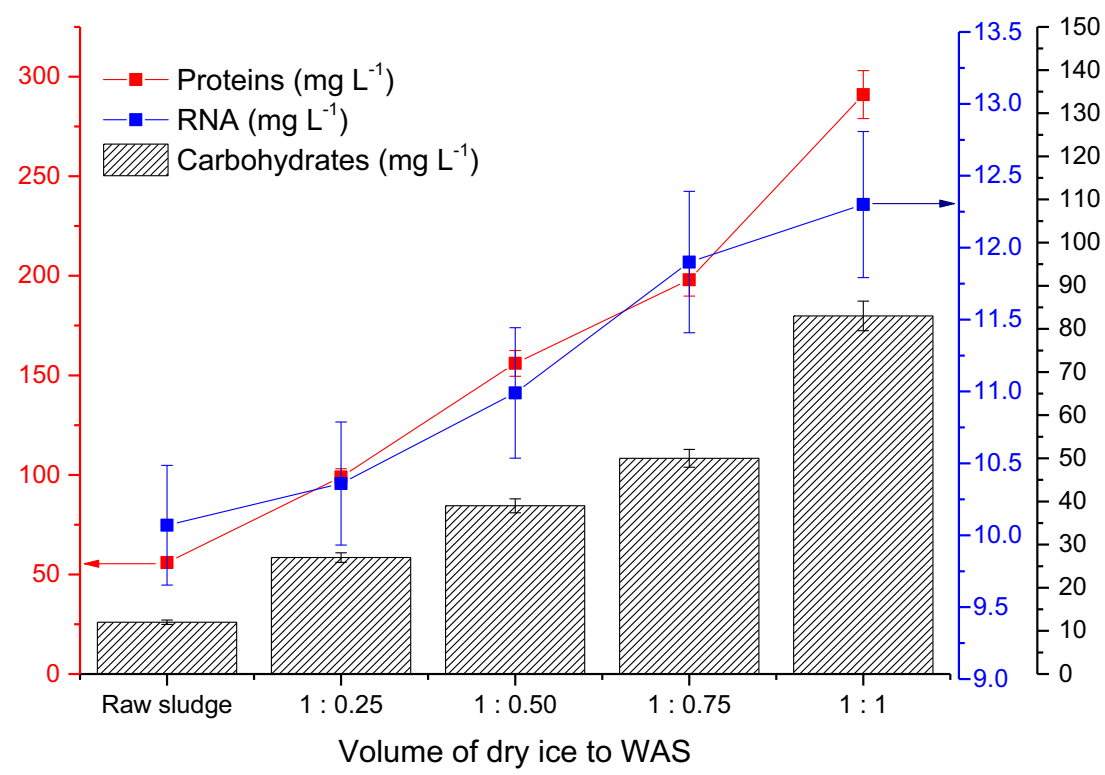


concentration of ammonium nitrogen and phosphates in liquid phase.

The dry ice action on the WAS resulted in gradual increase of ammonium nitrogen concentration in liquid and at the volume rate of WAS to dry ice of $1: 1$; the $\mathrm{N}-\mathrm{NH}_{4}{ }^{+}$concentration amounted to $24 \mathrm{mg} \mathrm{L}^{-1}$ (Fig. 4).

The process of freezing of WAS by dry ice contributed to the increase of concentration of phosphates with an initial value of $4.8 \mathrm{mg} \mathrm{PO}_{4}{ }^{3-} \mathrm{L}^{-1}$ (raw sludge) to $133 \mathrm{mg} \mathrm{PO}_{4}{ }^{3-}$ $\mathrm{L}^{-1}$ (the volume ratio of WAS to dry ice $1: 1$ ) (Fig. 4).

In 2011, Gao (2011) conducted laboratory tests of pretreatment of WAS, comparing freezing $\left(-18^{\circ} \mathrm{C}\right)$ of WAS with chemical methods (acidification: $\mathrm{pH} 5.5$, alkalisation: $\mathrm{pH}$ 11.0) and thermal $\left(60^{\circ} \mathrm{C}\right)$. He showed that freezing of WAS is an effective disintegration method, which resulted in an 8fold increase of SCOD and ammonia nitrogen and 2.5-fold increase of phosphates.

Montusiewicz et al. (2010) evaluated the effect of disintegration of sludge's via (using variable temperature) freezing on the properties of mixed sludge (real and waste) from municipal wastewater treatment plant. They examine the effects of the process of freezing on the quality of supernatant. The effect of freezing caused a $10 \%$ increase of concentration of nitrogen and phosphate compounds, which corresponds with the results obtained to some extent.

The obtained results confirm effective destruction of sludge flocs and 'cold' death of microorganisms caused by e.g. speed and time of freezing and thawing, chemical composition of sludge, bacterial species and temperature. For the mechanical destruction of the cells, in this destruction method, ice crystals are responsible, which damage them from the outside or inside (Örmeci and Aarne Vesilind 2001). The effect of this is the leakage of cellular components (organic and inorganic) over the shields into the liquid phase of sludge. In addition, the particular susceptibility to cold shock is mainly demonstrated by Gramnegative bacteria (they are present in large quantities in

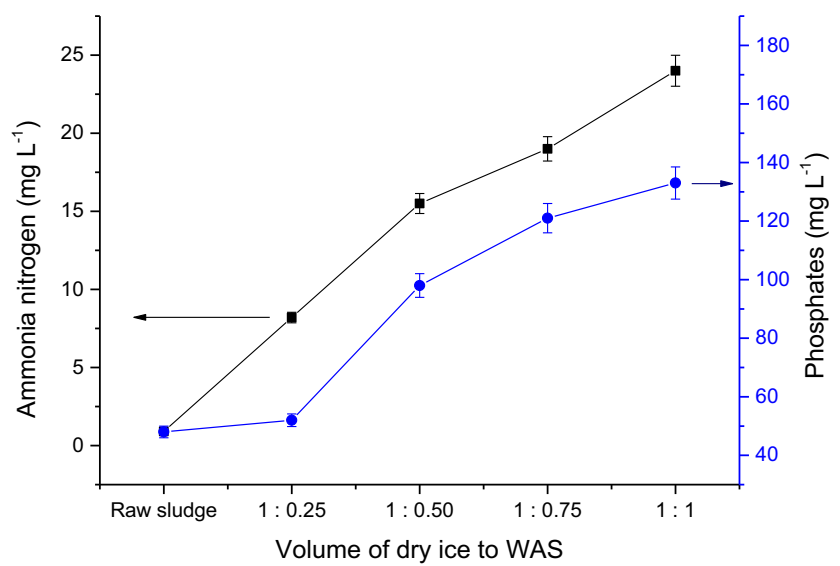

Fig. 4 Changes of ammonium nitrogen and phosphates concentration before and after disintegration of WAS by dry ice
WAS) and those that are at the logarithmic growth stage (Vollmer 2004).

Disintegration of WAS by dry ice led to an increase of turbidity of supernatant, which was caused by adding the suspension load and organic and inorganic colloids to the solution. The turbidity increased from the initial value of $57 \mathrm{mg}$ $\mathrm{SiO}_{2} \mathrm{~L}^{-1}$ for a raw sludge to the value of $410 \mathrm{mg} \mathrm{SiO}_{2} \mathrm{~L}^{-1}$ for the volume ratio of sludge to dry ice 1:1 (Fig. 5). Its changes were dependent on the volume ratio of sludge to dry ice, which was applied (Fig. 5).

Introduction of thermal WAS pretreatment in previous years aimed at improving the degree of mineralisation of sludge as well as its dewatering (Örmeci 2004; Diak et al. 2011). The dewatering of sewage sludges with the use of freezing takes place through separation of solid and liquid fractions during the formation of ice crystals. It was also found that this mechanism favours transformation of sediment flocs in agglomerates in a more compact and dense form (Hung et al. 1996; Jean et al. 2001).

The capillary suction time (CST) can be used as a good index for the ability to dewater of sludge. The test measures the time for free water to pass through a certain distance using suction paper as the medium (Chen et al. 1996). In this study, the dry ice action on the WAS resulted in decrease of CST from 46.2 to $22.8 \mathrm{~s}$ at the volume rate of WAS to dry ice of $1: 1$.

Wang et al. (2001) obtained over $82 \%$ increase of sludge dewaterability after sludge freezing compared with the untreated sludge. Additionally, they noted seven times better sludge dewaterability when slow-frozen process was applied in comparison with fast-frozen process.

The confirmation of physicochemical changes in supernatant was provided by an infrared spectroscopy research. The research results obtained confirm an increase of released and dissolved intracellular substances (Fig. 6).

IR is a technique used to obtain oscillatory and rotatory spectra. IR spectroscopy enables to establish which functional groups are present in an analysed sample. Infrared

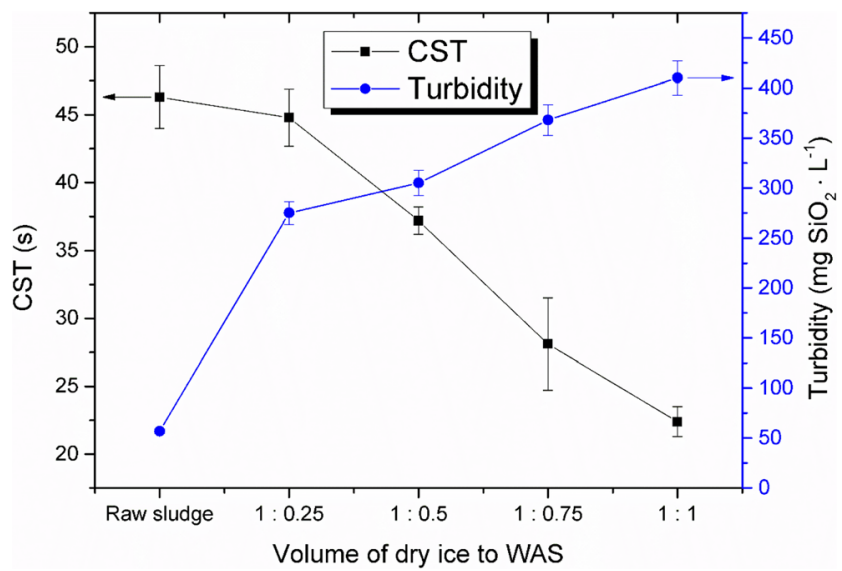

Fig. 5 Changes in the turbidity and capillary suction time (in the liquid phase) before and after disintegration of WAS by dry ice 


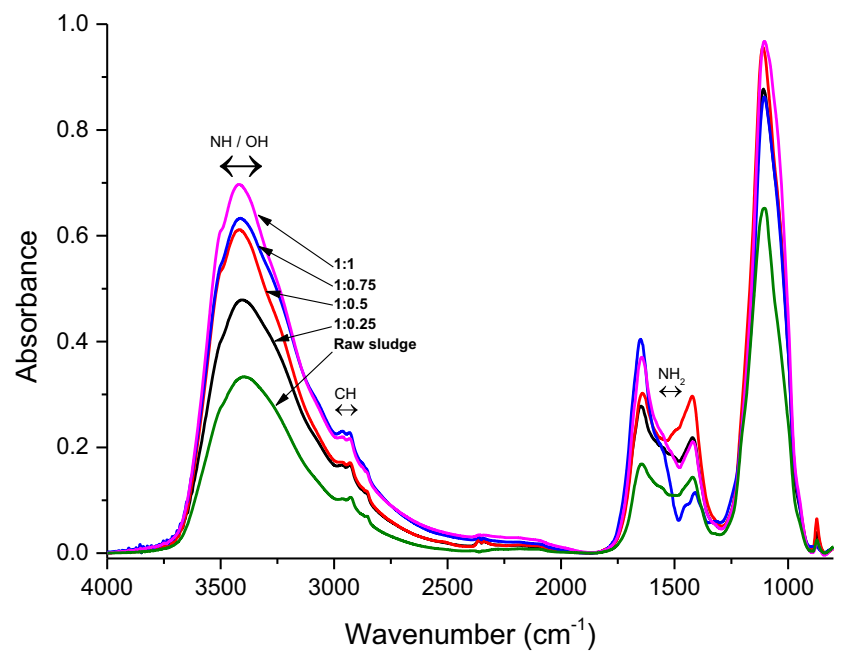

Fig. 6 Individual wavelengths characteristic for oscillators of chemical groups for freezing WAS disintegration

spectroscopy also enables particle structure analysis and their interaction with the environment. Two different chemical compounds will not have identical spectra in entire IR range and this ability allows for unambiguous identification of compounds.

Changes in the values of chemical parameters of liquid involved in the WAS depended on the volume ratio of WAS to dry ice which was applied. Following the increase in the volume of dry ice dose to WAS, greater changes in designated concentrations appeared. Considering influence of the process of freezing, it was found out that changes in chemical properties appeared in the samples due to the lysis of cells and release of enzymes. The use of thermal phenomena caused physicochemical reactions that have influenced the nature of distribution of substances present in the supernatant. Consequently, this led to the release of organic and inorganic matter and inter- and extracellular enzymes appearing in connections with colloid substances.

As was mentioned earlier, an increase in absorbance for individual wavelengths is very unique and characteristic for oscillators of chemical groups. The obtained results confirmed the differences in the liquid phase composition after application of WAS freezing (increased with the volume ratio of WAS to dry ice).

Analysing the changes in absorbance at a specific wavelength confirmed increase of the concentration of oscillators of tensile vibration for $\mathrm{O}-\mathrm{H}$ and $\mathrm{N}-\mathrm{H}$ compounds (at wavelengths around $3400 \mathrm{~cm}^{-1}$ ), S-H and $\mathrm{C}-\mathrm{H}$ (at wavelengths around $2900 \mathrm{~cm}^{-1}, 3000 \mathrm{~cm}^{-1}$ and $1400 \mathrm{~cm}^{-1}$ ), $\mathrm{C}=\mathrm{O}$ (at wavelengths around $1650 \mathrm{~cm}^{-1}$ ) and $\mathrm{C}-\mathrm{O}, \mathrm{P}-\mathrm{O}$ and $\mathrm{S}-\mathrm{O}$ (at wavelengths around $1100 \mathrm{~cm}^{-1}$ ) (Fig. 6) (Socrates 2007). These compounds are buildings cells of microorganisms and changes of them concentrations in liquid phase (suspensions) confirm the effective disintegration of applied freezing process.
The mentioned changes in absorbance at the specific wavelength are indicative of the release of i.e. amines, amino acids, proteins, phosphates, etc. Revealing these chemical groups in the supernatant attests to a destructive influence of freezing on WAS microorganisms and effective cellular lysis.

Dry ice in increased concentration caused further transformation of sludge what was revealed by the change in the intensity ratio of bands 1650 and $1420 \mathrm{~cm}^{-1}$. This can be related to the amine group transformation after the dry ice treatment (Silvestri et al. 2018b).

Moreover, there is a proportionally lesser absorbance increment for the 1:0.25 WAS to dry ice volume ratio than the 1:1 ratio. A smaller value in absorbance increment for the 1:0.25 ratio may have occurred due to the onset of homogenisation of the disintegrated medium, whereas the disintegration only increases for the 1:1 ratio.

The impact of the process of freezing by dry ice of sewage sludge on the increase of concentrations of organic and inorganic matter, determined by spectroscopic analysis, was confirmed using the IR analysis, which corresponds with the results obtained by Hu et al. (2011).

\section{Conclusions}

Calculations showed that the dry ice-WAS mixture, ratio 1:0.25, achieved the temperature $273.15 \mathrm{~K}$, whereas the mixture of solidified carbon dioxide and WAS, ratio 1:0.5, reached $267.15 \mathrm{~K}$. In mixtures, with the ratios of 1:0.75 and $1: 1$, the $\mathrm{CO}_{2}$ absorbed $558 \mathrm{~kJ}$ and $745 \mathrm{~kJ}$ of heat, respectively. This resulted in achieving mixtures that reached the temperature of dry ice sublimation. Moreover, as a result of disintegration of WAS by dry ice (in all ratios), a destruction of cellular structures of microorganisms appeared, and thus, there was an increase in SCOD, proteins, $\mathrm{RNA}, \mathrm{PO}_{4}{ }^{3-}, \mathrm{N}-$ $\mathrm{NH}_{4}{ }^{+}$and carbohydrate concentration in the sludge liquid. Furthermore, disintegration of WAS by dry ice caused an increase in the turbidity of supernatant and at the same time CST decreased which can be used as a good index for the ability to dewater WAS. FTIR analysis has confirmed the hypothesis of an efficient disintegration of WAS. That could be concluded from the changes in absorbance at the specific wavelengths, which corresponded to the presence of among others, amines, amino acids, proteins and phosphates. The separation of these substances in the supernatant confirms the destructive action on microorganisms (localised in WAS) and effective lysis of microorganisms cells.

Funding information The research presented in this article was supported by the Ministry of Education, Youth and Sports in the framework of the targeted support of the OPR \& DI project 'Extension of CxI facilities' (CZ.1.05/2.1.00/19.0386). The authors also received assistance from the Research Infrastructure NanoEnviCz, supported by the Ministry of Education, Youth and Sports of the Czech Republic under Project no. 
LM2015073. This work was supported by the Ministry of Education, Youth and Sports of the Czech Republic and the European UnionEuropean Structural and Investment Funds in the frames of Operational Program Research, Development and Education-Project Hybrid Materials for Hierarchical Structures (HyHi, Reg. No. CZ.02.1.01/0.0/ 0.0/16 019/0000843).

Open Access This article is distributed under the terms of the Creative Commons Attribution 4.0 International License (http:// creativecommons.org/licenses/by/4.0/), which permits unrestricted use, distribution, and reproduction in any medium, provided you give appropriate credit to the original author(s) and the source, provide a link to the Creative Commons license, and indicate if changes were made.

\section{References}

Ak MS, Muz M, Komesli OT, Gökçay CF (2013) Enhancement of biogas production and xenobiotics degradation during anaerobic sludge digestion by ozone treated feed sludge. Chem Eng J 230:499-505. https://doi.org/10.1016/J.CEJ.2013.06.113

Ali M, Zhang J, Raga R, Lavagnolo MC, Pivato A, Wang X, Zhang Y, Cossu R, Yue D (2018) Effectiveness of aerobic pretreatment of municipal solid waste for accelerating biogas generation during simulated landfilling. Front Env Sci Eng 12:5. https://doi.org/10.1007/ s11783-018-1031-1

Amano RS, Sunden B (2010) Computational fluid gynamics and heat transfer. In: R.S. Amano BS (ed) Computational fluid gynamics and heat transfer. WIT Press.

Aylin Alagöz B, Yenigün O, Erdinçler A (2018) Ultrasound assisted biogas production from co-digestion of wastewater sludges and agricultural wastes: comparison with microwave pre-treatment. Ultrason Sonochem 40:193-200. https://doi.org/10.1016/J. ULTSONCH.2017.05.014

Babatunde AO, Zhao YQ (2007) Constructive approaches toward water treatment works sludge management: an international review of beneficial reuses. Crit Rev Environ Sci Technol 37:129-164. https://doi.org/10.1080/10643380600776239

Carbajo JB, Petre AL, Rosal R, Berná A, Letón P, García-Calvo E, Perdigón-Melón JA (2016) Ozonation as pre-treatment of activated sludge process of a wastewater containing benzalkonium chloride and $\mathrm{NiO}$ nanoparticles. Chem Eng J 283:740-749. https://doi.org/ 10.1016/J.CEJ.2015.08.001

Carrère H, Dumas C, Battimelli A, Batstone DJ, Delgenès JP, Steyer JP, Ferrer I (2010) Pretreatment methods to improve sludge anaerobic degradability: a review. J Hazard Mater 183:1-15. https://doi.org/ 10.1016/j.jhazmat.2010.06.129

Chen GW, Lin WW, Lee DJ (1996) Capillary suction time (CST) as a measure of sludge dewaterability. Water Sci Technol 34:443-448. https://doi.org/10.1016/0273-1223(96)00610-5

Chen Y, Jiang J, Zhao Q (2014) Freezing/thawing effect on sewage sludge degradation and electricity generation in microbial fuel cell. Water Sci Technol 70:444-449. https://doi.org/10.2166/wst.2014. 226

Diak J, Örmeci B, Proux C (2011) Freeze-thaw treatment of RBC sludge from a remote mining exploration facility in subarctic Canada. Water Sci Technol 63:1309-1313. https://doi.org/10.2166/wst. 2011.376

Gao W (2011) Freezing as a combined wastewater sludge pretreatment and conditioning method. Desalination 268:170-173. https://doi. org/10.1016/J.DESAL.2010.10.014

Gebreeyessus GD, Jenicek P (2016) Thermophilic versus mesophilic anaerobic digestion of sewage sludge: a comparative review.
Bioengineering (Basel) 3. https://doi.org/10.3390/ bioengineering3020015

Gerhardt P, Murray RGE, Wood WA, Krieg NR (1994) Methods for general and molecular bacteriology. John Wiley \& Sons, Ltd, Washington, D.C

Gogate PR, Shirgaonkar IZ, Sivakumar M, Senthilkumar P, Vichare NP, Pandit AB (2001) Cavitation reactors: efficiency assessment using a model reaction. AICHE J 47:2526-2538. https://doi.org/10.1002/ aic. 690471115

Grübel K, Machnicka A (2013) Infrared wave analysis after hydrodynamic and acoustic cavitation as effective method of confirming sewage sludge destruction. J. Environ Sci Health A 49(1):101-107. https:// doi.org/10.1080/10934529.2013.824738

Grübel K, Suschka J (2015) Hybrid alkali-hydrodynamic disintegration of waste-activated sludge before two-stage anaerobic digestion process. Environ Sci Pollut Res 22:7258-7270. https://doi.org/10.1007/ s11356-014-3705-y

Grübel K, Machnicka A, Nowicka E, Wacławek S (2014) Mesophilicthermophilic fermentation process of waste activated sludge after hybrid disintegration. Ecol Chem Eng S 21:125-136. https://doi. org/10.2478/eces-2014-0011

Grübel K, Wacławek S, Machnicka A, Nowicka E (2018) Synergetic disintegration of waste activated sludge: improvement of anaerobic digestion and hygienization of sludge. J Environ Sci Health A 53: 1067-1074. https://doi.org/10.1080/10934529.2018.1474579

Gugulothu R, Sanke N, Gupta AVSSKS (2019) Numerical study of heat transfer characteristics in shell-and-tube heat exchanger. In: Srinivasacharya D, Reddy K (eds) Numerical heat transfer and fluid flow. Lecture Notes in Mechanical Engineering. Springer, Singapore, pp 375-383. https://doi.org/10.1007/978-981-13-1903743

Hu J, Johnston KP, Williams RO (2004) Rapid dissolving high potency danazol powders produced by spray freezing into liquid process. Int J Pharm 271:145-154. https://doi.org/10.1016/j.ijpharm.2003.11. 003

Hu K, Jiang J-Q, Zhao Q-L, Lee DJ, Wang K, Qiu W (2011) Conditioning of wastewater sludge using freezing and thawing: role of curing. Water Res 45:5969-5976. https://doi.org/10.1016/j. watres.2011.08.064

Hung WT, Chang IL, Lin WW, Lee DJ (1996) Unidirectional freezing of waste-activated sludges: effects of freezing speed. Environ Sci Technol 30:2391-2396. https://doi.org/10.1021/ES950889X

Ismalaj T, Sackett DL (2015) An inexpensive replacement for dry ice in the laboratory. Anal Biochem 474:38-39. https://doi.org/10.1016/j. ab.2015.01.008

Jang HM, Cho HU, Park SK, Ha JH, Park JM (2014) Influence of thermophilic aerobic digestion as a sludge pre-treatment and solids retention time of mesophilic anaerobic digestion on the methane production, sludge digestion and microbial communities in a sequential digestion process. Water Res 48:1-14. https://doi.org/10.1016/J. WATRES.2013.06.041

Jean DS, Lee DJ, Chang CY (2001) Direct sludge freezing using dry ice. Adv Environ Res 5:145-150. https://doi.org/10.1016/S10930191(00)00052-6

Jeyasekaran G, Ganesan P, Anandaraj R, Jeya Shakila R, Sukumar D (2006) Quantitative and qualitative studies on the bacteriological quality of Indian white shrimp (Penaeus indicus) stored in dry ice. Food Microbiol 23:526-533. https://doi.org/10.1016/J.FM.2005.09. 009

Kardos L, Juhász A, Palkó GY et al (2011) Comparing of mesophilic and thermophilic anaerobic fermented sewage sludge based on chemical and biochemical tests. Appl Ecol Environ Res 9:293-302. https:// doi.org/10.15666/aeer/0903 293302

Kavitha S, Jayashree C, Adish Kumar S, Yeom IT, Rajesh Banu J (2014) The enhancement of anaerobic biodegradability of waste activated sludge by surfactant mediated biological pretreatment. Bioresour 
Technol 168:159-166. https://doi.org/10.1016/J.BIORTECH.2014. 01.118

Kidak R, Wilhelm A-M, Delmas H (2009) Effect of process parameters on the energy requirement in ultrasonical treatment of waste sludge. Chem Eng Process Process Intensif 48:1346-1352. https://doi.org/ 10.1016/J.CEP.2009.06.010

Kim C, Ahn J-Y, Kim TY, Shin WS, Hwang I (2018) Activation of persulfate by nanosized zero-valent iron (NZVI): mechanisms and transformation products of NZVI. Environ Sci Technol 52:36253633. https://doi.org/10.1021/acs.est.7b05847

Kreith F, Tchobanoglous G (2002) Handbook of solid waste management. McGraw-Hill, New York

Kuglarz M, Grübel K, Bohdziewicz J (2014) Post-digestion liquor treatment in the method combining chemical precipitation with reverse osmosis. Arch Environ Prot 40:29-42. https://doi.org/10.2478/aep2014-0030

Li Y, Yuan X, Wu Z, Wang H, Xiao Z, Wu Y, Chen X, Zeng G (2016) Enhancing the sludge dewaterability by electrolysis/ electrocoagulation combined with zero-valent iron activated persulfate process. Chem Eng J 303:636-645. https://doi.org/10.1016/j. cej.2016.06.041

Liu J, Wei Y, Li K, Tong J, Wang Y, Jia R (2016) Microwave-acid pretreatment: a potential process for enhancing sludge dewaterability. Water Res 90:225-234. https://doi.org/10.1016/j. watres.2015.12.012

Liu X, Xu Q, Wang D, Zhao J, Wu Y, Liu Y, Ni BJ, Wang Q, Zeng G, Li $X$, Yang $Q$ (2018) Improved methane production from waste activated sludge by combining free ammonia with heat pretreatment: Performance, mechanisms and applications. Bioresour Technol 268: 230-236. https://doi.org/10.1016/J.BIORTECH.2018.07.109

Liu X, Xu Q, Wang D, Wu Y, Yang Q, Liu Y, Wang Q, Li X, Li H, Zeng G, Yang G (2019) Unveiling the mechanisms of how cationic polyacrylamide affects short-chain fatty acids accumulation during longterm anaerobic fermentation of waste activated sludge. Water Res 155:142-151. https://doi.org/10.1016/J.WATRES.2019.02.036

Liwarska-Bizukojc E, Ledakowicz S (2001) RNA assay as a method of viable biomass determination in the organic fraction of municipal solid waste suspension. Biotechnol Lett 23:1057-1060. https://doi. org/10.1023/A:1010550205658

Lü F, Wang J, Shao L, He P (2016) Enzyme disintegration with spatial resolution reveals different distributions of sludge extracellular polymer substances. Biotechnol Biofuels 9:29. https://doi.org/10.1186/ s13068-016-0444-y

Lu J, Dong W, Ji Y, Kong D, Huang Q (2016) Natural organic matter exposed to sulfate radicals increases its potential to form halogenated disinfection byproducts. Environ Sci Technol 50:5060-5067. https://doi.org/10.1021/acs.est.6b00327

Machnicka A, Grübel K (2016) Investigation of the effectiveness of nutrient release from sludge foam after hybrid pretreatment processes by IR analysis and EDX Quantification. Environ Technol (United Kingdom) 37:3120-3130. https://doi.org/10.1080/09593330.2016. 1177120

Mirota K, Grübel K, Machnicka A (2011) Design and assessment of cavitational device for enhancement of sewage sludge fermentation. Ochr Sr 33:47-52

Montusiewicz A, Lebiocka M, Rożej A, Zacharska E, Pawłowski L (2010) Freezing/thawing effects on anaerobic digestion of mixed sewage sludge. Bioresour Technol 101:3466-3473. https://doi.org/ 10.1016/J.BIORTECH.2009.12.125

Müller J (2000) Disintegration as a key-step in sewage sludge treatment. Water Sci Technol 41:123-130. https://doi.org/10.2166/wst.2000. 0151

Nowicka E, Machnicka A (2015) Hygienization of surplus activated sludge by dry ice. Ecol Chem Eng S 21:651-660. https://doi.org/ 10.1515/eces-2014-0047
Örmeci B (2004) Freeze-thaw conditioning of activated sludge: effect of monovalent, divalent and trivalent cations. J Residuals Sci Tech 1: 143-150. doi: 1544-8053/04/03

Örmeci B, Aarne Vesilind P (2001) Effect of dissolved organic material and cations on freeze-thaw conditioning of activated and alum sludges. Water Res 35:4299-4306. https://doi.org/10.1016/S00431354(01)00174-9

Parthiba Karthikeyan O, Trably E, Mehariya S, Bernet N, Wong JWC, Carrere H (2018) Pretreatment of food waste for methane and hydrogen recovery: a review. Bioresour Technol 249:1025-1039. https://doi.org/10.1016/J.BIORTECH.2017.09.105

Pérez-Elvira SI, Nieto Diez P, Fdz-Polanco F (2006) Sludge minimisation technologies. Rev Environ Sci Bio 5:375-398. https://doi.org/10. 1007/s11157-005-5728-9

Pilli S, Yan S, Tyagi RD, Surampalli RY (2015) Thermal pretreatment of sewage sludge to enhance anaerobic digestion: a review. Crit Rev Environ Sci Technol 45:669-702. https://doi.org/10.1080/ 10643389.2013.876527

Rice EW, Bridgewater L (2012) Standard methods for the examination of water and wastewater. American Public Health Association.

Şahinkaya S, Sevimli MF (2013) Synergistic effects of sono-alkaline pretreatment on anaerobic biodegradability of waste activated sludge. J Ind Eng Chem 19:197-206. https://doi.org/10.1016/J. JIEC.2012.08.002

Seviour RJ, Nielsen PH (2010) Microbial ecology of activated sludge. IWA Publishing

Sharma A, Tyagi VV, Chen CR, Buddhi D (2009) Review on thermal energy storage with phase change materials and applications. Renew Sust Energ Rev 13:318-345. https://doi.org/10.1016/J.RSER.2007. 10.005

Silvestre G, Ruiz B, Fiter M, Ferrer C, Berlanga JG, Alonso S, Canut A (2015) Ozonation as a pre-treatment for anaerobic digestion of waste-activated sludge: Effect of the ozone doses. Ozone Sci Eng 37:316-322. https://doi.org/10.1080/01919512.2014.985817

Silvestri D, Wacławek S, Gončuková Z, Padil VVT, Grübel K, Černík M (2018a) A new method for assessment of the sludge disintegration degree with the use of differential centrifugal sedimentation. Environ Technol (United Kingdom):1-8. https://doi.org/10.1080/ 09593330.2018.1477839

Silvestri D, Wacławek S, Sobel B, Torres-Mendieta R, Novotný V, Nguyen NHA, Ševců A, Padil VVT, Müllerová J, Stuchlík M, Papini MP, Černík M, Varma RS (2018b) A poly(3hydroxybutyrate)-chitosan polymer conjugate for the synthesis of safer gold nanoparticles and their applications. Green Chem 20: 4975-4982. https://doi.org/10.1039/c8gc02495b

Socrates G (2007) Infrared and raman characteristic group frequencies: tables and charts. John Wiley \& Sons

Suschka J, Grübel K (2016) Low intensity surplus activated sludge pretreatment before anaerobic digestion. Arch Environ Prot 43:50-57. https://doi.org/10.1515/aep-2017-0038

Suschka J, Kowalski E, Mazierski J, Grübel K (2015) Alkaline solubilisation of waste activated sludge (WAS) for soluble organic substrate - (SCOD) production. Arch Environ Prot 41:29-34. https://doi.org/10.1515/aep-2015-0012

Tyagi VK, Lo SL (2011) Application of physico-chemical pretreatment methods to enhance the sludge disintegration and subsequent anaerobic digestion: an up to date review. Rev Environ Sci Biotechnol 10: 215-242. https://doi.org/10.1007/s11157-011-9244-9

Uma Rani R, Adish Kumar S, Kaliappan S, Yeom IT, Banu JR (2014) Enhancing the anaerobic digestion potential of dairy waste activated sludge by two step sono-alkalization pretreatment. Ultrason Sonochem 21:1065-1074. https://doi.org/10.1016/j.ultsonch.2013. 11.007

Vollmer M (2004) Physics of the microwave oven. Phys Educ 39:74-81. https://doi.org/10.1088/0031-9120/39/1/006 
Wacławek S, Grübel K, Dennis P, Vinod VTP, Černík M (2016) A novel approach for simultaneous improvement of dewaterability, postdigestion liquor properties and toluene removal from anaerobically digested sludge. Chem Eng J 291:192-198. https://doi.org/10.1016/ j.cej.2016.01.103

Wacławek S, Lutze HV, Grübel K, Vinod VTP, Černík M, Dionysiou DD (2017) Chemistry of persulfates in water and wastewater treatment: a review. Chem Eng J 330:44-62. https://doi.org/10.1016/j.cej. 2017.07.132

Wang Q, Kuninobu M, Kakimoto K et al (1999) Upgrading of anaerobic digestion of waste activated sludge by ultrasonic pretreatment. Bioresour Technol 68:309-313. https://doi.org/10.1016/S09608524(98)00155-2

Wang Q, Fujisaki K, Ohsumi Y, Ogawa HI (2001) Enhancement of dewaterability of thickened waste activated sludge by freezing and thawing treatment. J Environ Sci Health A 36:1361-1371. https:// doi.org/10.1081/ESE-100104884

Wang Q, Jiang G, Ye L, Yuan Z (2014) Enhancing methane production from waste activated sludge using combined free nitrous acid and heat pre-treatment. Water Res 63:71-80. https://doi.org/10.1016/j. watres.2014.06.010

Wett B, Phothilangka P, Eladawy A (2010) Systematic comparison of mechanical and thermal sludge disintegration technologies. Waste Manag 30:1057-1062. https://doi.org/10.1016/j.wasman.2009.12. 011

Wiktor A, Schulz M, Voigt E, Knorr D, Witrowa-Rajchert D (2015) Impact of pulsed electric field on kinetics of immersion freezing, thawing, and on mechanical properties of carrot. ZYWN-NAUK TECHNOL JA 21:124-137. https://doi.org/10.15193/zntj/2015/99/ 027

Wójcik M, Stachowicz F, Masłon A (2017) The possibility of sewage sludge conditioning and dewatering with the use of biomass ashes. Eng Prot Environ 20:153-164. https://doi.org/10.17512/ios.2017.2. 1

Xu Q, Liu X, Fu Y, Li Y, Wang D, Wang Q, Liu Y, An H, Zhao J, Wu Y, Li X, Yang Q, Zeng G (2018) Feasibility of enhancing short-chain fatty acids production from waste activated sludge after free ammonia pretreatment: role and significance of rhamnolipid. Bioresour Technol 267:141-148. https://doi.org/10.1016/J.BIORTECH.2018. 07.018
Yan Y, Liu Q, Wang K, Jiang L, Yang X, Qian J, Dong X, Qiu B (2013) Enhanced peroxydisulfate electrochemiluminescence for dopamine biosensing based on Au nanoparticle decorated reduced graphene oxide. Analyst 138:7101-7106. https://doi.org/10.1039/c3an01533e

Yi WG, Lo KV, Mavinic DS (2014) Effects of microwave, ultrasonic and enzymatic treatment on chemical and physical properties of wasteactivated sludge. J Environ Sci Health A 49:203-209. https://doi. org/10.1080/10934529.2013.838880

Yu G-H, He P-J, Shao L-M, Zhu Y-S (2008) Extracellular proteins, polysaccharides and enzymes impact on sludge aerobic digestion after ultrasonic pretreatment. Water Res 42:1925-1934. https://doi.org/ 10.1016/j.watres.2007.11.022

Zaia DAM, Verri WA, Zaia CTBV (2000) Determination of total proteins in several tissues of rat: a comparative study among spectrophotometric methods. Microchem J 64:235-239. https://doi.org/10.1016/ S0026-265X(00)00017-5

Zalba B, Marín JM, Cabeza LF, Mehling H (2003) Review on thermal energy storage with phase change: materials, heat transfer analysis and applications. Appl Therm Eng 23:251-283. https://doi.org/10. 1016/S1359-4311(02)00192-8

Zhang Y, Zhang P, Ma B, Wu H, Zhang S, Xu X (2012) Sewage sludge disintegration by high-pressure homogenization: a sludge disintegration model. J Environ Sci (China) 24:814-820. https://doi.org/ 10.1016/S1001-0742(11)60834-6

Zhang S, Guo H, Du L, Liang J, Lu X, Li N, Zhang K (2015) Influence of $\mathrm{NaOH}$ and thermal pretreatment on dewatered activated sludge solubilisation and subsequent anaerobic digestion: focused on high-solid state. Bioresour Technol 185:171-177. https://doi.org/ 10.1016/j.biortech.2015.02.050

Zhou Z, Yang Y, Li X (2015) Effects of ultrasound pretreatment on the characteristic evolutions of drinking water treatment sludge and its impact on coagulation property of sludge recycling process. Ultrason Sonochem 27:62-71. https://doi.org/10.1016/j.ultsonch. 2015.04.018

Publisher's note Springer Nature remains neutral with regard to jurisdictional claims in published maps and institutional affiliations. 